\title{
Gender Role Stereotyping Of Women As Housewives In Conventional Pakistani Society
}

\author{
Amna Saeed \\ \& \\ Noreen Zainab \\ Department of Humanities \\ COMSATS Institute of Information Technology, Islamabad
}

\begin{abstract}
This study aims to analyze the short story, The Spell and the Ever Changing Moon (2014) by Rukhsana Ahmad, from the feminist perspective. A close reading of the text reveals that facing everyday challenges and juggling between multiple roles is a common practice for middleclass house wives in Pakistani society. The economic instabilities added with emotional, psychological as well as physical abuse plays a vital role in their oppression and humiliation on regular basis. These roles as assigned to them define their social standing and suffering becomes their destiny. Multiple roles of such women and social expectations outside and inside the house define their way of living. Each and every movement and thought becomes codependent on their social familial roles. Being selfless becomes an obligation and 'sacrifice' becomes convention for middle class women who spend their whole lives living under the thumb of their men folk. Moreover, the movement and status of women inside and outside the home is also a major concern addressed in this paper including the concept of home, and its significance in lives of Pakistani women.
\end{abstract}

Keywords: Housewives, Gender Roles, Stereotyping, Domestic Abuse, Power Practice.

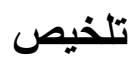

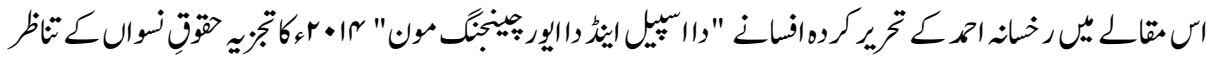

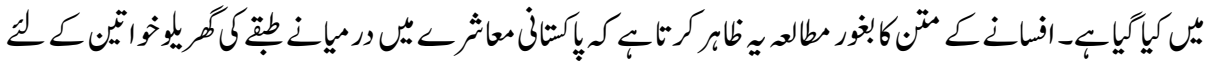

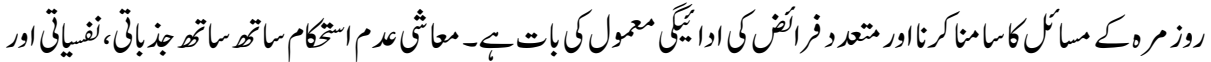

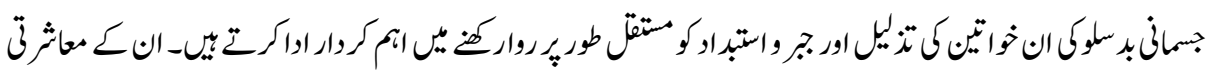

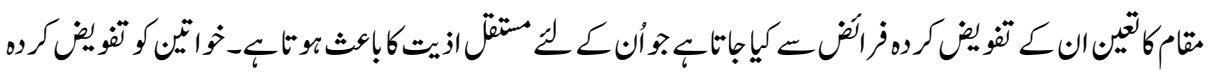

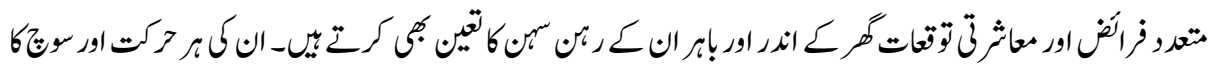

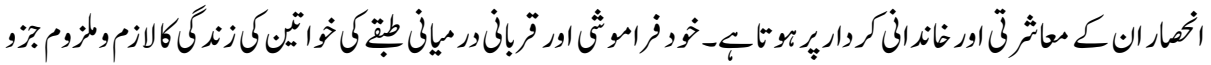




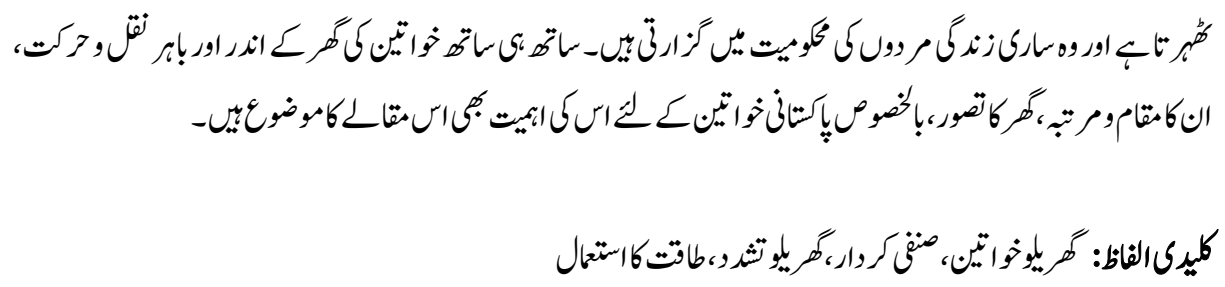

\section{Introduction}

The present study aims to investigate the gender stereotyping of women as housewives in Pakistani society through the experiences of the character Nisa in Rukhsana Ahmad's story The Spell and the Ever Changing Moon (2014). The study is focused on the issues of gender roles assigned to middle class house wives in Pakistan as viewed from the feminist lens. In Pakistani society, men usually have the dominant roles in family and home like the 'decision maker' and the immediate 'authority'. The "power gradient" granted to them by the prevailing culture assists them in suppressing women as a natural process. This typically puts men in roles of bread earners and decision makers in the family while women are expected to take care of the household chores and serve men (Ali, Krantz, Gul, Asad, Johansson \& Mogren, 2011). The power granted to men also marks the position of women in Pakistani society as weak, defenseless and dependent on men for their basic needs including finances (Chaudhary, 2005). They are culturally confined within the limits of the home and their major/only role in the family is perceived to be re/producers/caretakers of children (Jalal-ud-Din \& Khan, 2008). Men therefore, are the decision makers and women are forced to adhere to the decisions men make for them in the name of family honor and to maintain the patriarchal ideologies prevalent in society (Saeed \& Khan, 2017). This dependence and passive acceptance of the power men practice on women in different forms is the central concern in the lives of middle class housewives.

In Pakistani society where women are trained as efficient housewives from early childhood, boys are taught to be strong and domineering in the confines of the house. The role of men in the household is that of custodians and protectors of family interests and family honor. They are taught to preserve the family name in an honorable fashion no matter what measures they have to adopt to achieve the said aim (Fikree \& Pasha, 2004). Men are trained to rule their women as their natural right; they therefore see women only as means of conjugal consummation, reproduction, and the caretakers of the household chores. Bhattacharya (2014: 186) explains that "the trend of male dominance becomes a factor causing violence to the other gender. Women are viewed inferior to be "reined in" by men for the better or, in the majority of cases, for the worse." As a result, many a time men fail to differentiate between abuse as power practice on their part since such practices are made to appear as 'normal' male behavior in the house hold setting. The 
most common forms of abuse in a marital relationship, for women as housewives, are thus economic, sexual, physical and emotional. The pious character of women and closeness to religion associated with women's identity is the reason she bears this physical humiliation by her husband. Spence \& Helmreich (1980) talk about the individual view of sexuality which refers to the identity of an individual as a masculine or feminine.

Rukhsana Ahmad's story The Spell and the Ever Changing Moon (2014) is a deep criticism on the social structures which always place men in dominant roles in family. This story being written specifically in Pakistani context deals with the lower-middle class characters, specifically the house wife in a conventional Pakistani family. The whole story revolves around the life experiences of Nisa, each and every aspect of the story is the clear representation of social structures which impose gender roles on men as well as women. Women being less powerful suffer the consequences of this power hierarchy. The reader from the very opening of the story becomes engaged in the life of Nisa, whose each and every movement is ruled by fear. Nisa the main protagonist of the story is the center of attention, the word Nisa is basically an Arabic word which means "a woman", it gives us an indication that this character stands for the face of feminity, womanhood in general and circumstances associated with being woman in Pakistani society. From outside towards inside of her house the reader can see through her fears and struggles being a woman belonging to a strong patriarchal background. Nisa being a woman living in conservative society, a small town community was expected to perform multiple roles at the same time, each role with a set of expected characteristics. We come to know at many instances that she is obliged to perform those roles, as those social roles are imposed on her from the very early stages, reinforced by her mother and other members of family as well as society.

\section{Methodology}

The present study is qualitative in its nature and the short story The Spell and the Ever Changing Moon (2014) is critically analyzed from feminist perspective via a close reading of the text. Feminist literary criticism not only examines the status/role/sufferings/issues of women in society but also challenges the very structure of the culture that gives rise to them. It is therefore a social critique of all the forces/laws/institutions that assert domination on women in a culture (Ruthven, 1984). A close reading of the selected text here essentially draws upon the persona of the character of Nisa and analyses, through her social position/actions, the gender stereotyping of a house wife in the context of Pakistani middle class society (Kusch, 2016). Furthermore the study is based on the framework of relevant theories of gender and feminism. Through selected events/actions in language of the text, the study critically examines the gender status/roles of 
women as house wives and what are the socio-cultural implications of such stereotyping of women. In addition, the role of men as dominant caretakers of the house is also studied in the context of domestic violence/abuse and women's sufferings since feminist literature typically incorporates 'gender and politics' and while it affirms the issues of women in general, it also caters to the position of men in relation to the social status/position of women (Kuhlemann, 2016).

\section{Construction of Gender Role Stereotypes}

Gender is much more than biological sex of a person; it is the socio-cultural definition of men and women. Worell (2002) defines sex as "biological difference" among individuals and gender is considered to be the "physiological, social and cultural characteristics being associated with the biological categories both female as well as male" (p.265). Gender is defined not only by the biological differences but also on the basis of social expectations and social roles of both men and women (Kruger, 1997). Moreover, it is the cultural power politics and social understanding of relationships that define not only human nature/identity but also the gender performative roles of men and women (Butler, 1990). Lorber \& Farrell (1991: 104) state:

Gendered people emerge not from physiology or sexual orientations but from the exigencies of social order, mostly from the need of a reliable division of work of food production and the social (not physical) reproduction of new members.

The Cognitive Developmental Theory describes the process of gender awareness and realization as a two-step process. First step is the realization of one's sex, and second step is the association with masculinity or feminity with one's character (Freud, 1927; Kohlberg, 1966; Chodorow, 1978; Weitzman, 1979). Among the multiple socio-cultural institutions it is the family that plays the most important role in the construction of gender identity/roles in children which become a part of their personalities as adults. During this process of gender awareness parents play the most important role for children (Hussain, Naz, Khan, Daraz \& Khan, 2015)

Gender role stereotypes are the specific characteristics that are associated with the roles of the masculine and feminine in society (Stets \& Burkes, 1996). When gender roles become part of our culture they grow into gender stereotypes which then define the way of life for people of a particular society (Welter, 1966). Although different institutions in society play vital role in the construction of gender stereotypes in society, however family is considered to be the most important in inculcating gender specific behavioral norms in people. Parents' perceptions regarding the competencies of their children based on gender become the most crucial factor in developing gender role stereotypes in society. Based on these parents' classify activities/ performances and roles for their children 
which remain a part of their characters for the rest of their lives. (Eccles, Jacobs \& Harold, 1990). In Pakistani society, where boys from early childhood are taught to rule women, construction of gender stereotypes affects girls more than boys. This gender stereotyping allows "differential treatment of parents to view their daughters as delicate, weak, emotional, sensitive, and dependent, and sons as strong, aggressive, brave, and independent encourages children to behave respectfully" (Hussain, et al. 2015:9). As adults, therefore, the same stereotypical patterns of gender unconsciously allow women to submit to violence, abuse and unequal treatment when it comes to their rights of education, health and employment. This typical unequal treatment of women is based on the fact that women are considered important only for reproduction and house hold service (Hussain, Habib \& Akhter, 2014).

\section{Womanhood and the Ideal of Morality}

Gilligan (1982) in her theory of "difference feminism" argues that the idea of morality for women is related to the concept of "care and responsibility" so being moral for a woman is to be caring and sacrificing for her loved ones. Ali, Krantz, Gul, Asad, Johansson \& Mogren (2011) explain the position of the "woman" in Pakistani household as:

A 'good woman' could be either educated or uneducated, characterized as being unselfish, calm, tolerant, empathetic, reliable, able to organize, compromise, coordinate and maintain hospitality within the house and in keeping good relationships. A good woman was expected to do household chores, care for her children, husband and in-laws and when needed provide the home with external income. A woman was expected to hide her emotions, to compromise with her opinions and to sacrifice her own dreams. The informants reported that some women perceived their husband to be their owner and ruler and therefore they should acquire their husbands' permission to perform any activity.

Piety is strength of women in our society; so they are taught to be pious from early childhood as they are considered responsible for improvement of this world, to bring goodness and revolution. Welter (1966:152) observes that "religion and piety are considered to be the core of women's virtue". On the other hand, she is also considered to be the one who brings downfall of man, from heaven to earth a reason for evil, for first murder and all the sins, which followed (Nashua, 1849).

\section{Household as Unpaid Domestic Labor}

One important factor which leads to exploitation of women in the stereotypical role of a house wife in Pakistani society is the fact that they are not independent financially. Isran \& Isran (2012, p.454) observe: 
Women are economically invisible. By gaining economic empowerment, they will get both visibility and a voice in decision-making process within the household, workplace and in society. By giving equal economic opportunities, they not only would contribute to the earnings of household but also become major contributors or equal to men to nation economy. As women gain economic strength, the attitudes of their family members and society, as a whole towards them would change.

Another important gender stereotype regarding third world countries is the division of labor among men and women. Household chores are included in the responsibility list of a house wife and husbands don't generally play any role in management of house instead they are associated with employment and earning finances (Eagly \& Steffen, 1984). Godey (1839) says that women should make house a happy place for their men so they come to home and forget all the frustrations. The expected role assigned to women is to take care of their children, perform all the household chores and make her children and husband happy and content in all the possible ways. Men on the other hand are responsible for the economic affairs of the house (Welter, 1966). Delphy (1984, p.60) states that "marriage is a labor contract that ties women to unpaid domestic labor". She further says that this unpaid labor is the "housework" which further is not considered important enough to be considered part of the debate and problem. The most important part of her research states that "it is not because their work is less important or involve less effort and labor but because patriarchy defines women in their domestic roles as non-workers" (p.61). The unpaid nature of housework and an inferior position assigned to housewives is because of the established fact that it is instinctive responsibility of women to take care of their houses and their children (Waring, 1998). Also as socio-cultural practice, men are preferred over women on the basis of their "value, and participation in work force" whereas women on the basis of their sexual identity (Guillaumin, 1996:73).

Therefore, Salter (1970) claims that "the housewife is nobody" since it is the husband who provides for the maintenance of household. He becomes powerful and his status is increased to the extant where he can look down upon his own wife and think of her as dependent on him, for everything which makes him the ultimate power and authority.

Nonetheless, the paid nature of men's job does not make him supreme power, if money is the way to run household than without house wife it is not possible to have a house. Riesman (1964) reminds us that without women nothing could be done. The whole super structure of economy rests on the shoulders of house wives. If women don't care for the households and workers, government would be responsible for it, as in case of military while women do it for free. 


\section{Data Analysis}

Nisa, like any other girl in a conservative Pakistani family, from the very early stage of life is repeatedly being told by her mother through words as well as practical examples, the norms of right and wrong. For example, the behavioral patterns "allowed" to follow when in company of men and the ones that are not. Who is the in charge and authority in household. The role of a woman, as a wife, a daughter and a sister in the limits of the house is reinforced by mothers during the period of character development and identity formation of girls which ultimately becomes part of their cognitive system.

In the very opening of the story we come to know that Nisa is going somewhere, a place where she knows that "it's not permitted" and thus she is "trembling a little with guilt and fear, her heartbeat quickening" (Ahmad, 2014:144). This physical description of her fear, being a married woman, an adult individual seems to be the part of cultural practices where men decide for their women what they can and cannot do and what is permitted and what not.

The role and authority of men outside the house is also portrayed beautifully by the writer in the very next scene of the story. Two men working as mechanics on the road "looked up from their sweaty labor each time a woman went in or out of the green door of Talat's house" (Ahmad, 2014:144). The role of men in society is also reinforced by their role models and their peers and become the mainstream attitude of people, which becomes the standard of normality in society. It is a ritual, a routine for those men to stare at each and every woman who passed through their way, "they were not discouraged by the veils and cloaks. If the outline or gait indicated the presence of youngish woman they did their best to draw her attention by shouting or humming a snatch of film song" (p.145). The reaction of Nisa when those men stare at her is ironically a reflection of the male dominated society of Pakistan and a kind of behavior preferred, adopted, practiced and taught by all women to avoid conflict and any unpleasant situation in public sphere by women.

The women had been trained for years to side step and ignore this kind of behavior. They all scurried past hastening their footsteps just a little. Nisa, skilled in that strategy quickened her pace (Ahmad, 2014:145).

The important words here are "trained" and "skilled" as they show us the deep rootedness of these practices in society, to the extent that they become part of culture. Multiple generations of women are raised teaching and learning these skills, the rules for their survival in the male dominated society in Pakistan. In order to restore their piety women have to adopt such ways and learn such skills. This is what is expected of them by society and by all their family members other women included. Resistance by women to male chauvinism is taken as negative attribute, even evil at times by the society. 
The movement of women and their status in the world outside their homes is also depicted wonderfully in the given situation of the story

Her mother had always stressed the dignity and value of reserve 'A good woman' she used to say, knows how to keep the family secrets

She further recalls her mother's teachings "if possible you manage to survive without letting the world know" (Ahmad, 2014:145). Nisa considers herself a bad woman as she could not hide her "dark secret" from the neighbors, when her husband screams at her and abuses her physically very late at night. The term used for such teachings is silencing where the possessed is forbidden to say something.

Nisa when sees an elderly relative lecturing a bride at a wedding ceremony loses control. She fails to remain quite when she hears her using words "forbearance and forgiveness" again and again. These two principles are very commonly taught to women when they are married off, in order to cope up with their new lives. The questions she raises are not welcomed and she is being criticized for expressing her unsettling view, questions no one had an answer to. A few questions she asks are the questions every girl in our society asks herself or her family, friends, and relatives at one stage of her life or another:

How much exactly is she really supposed to endure, chichi? How many tears does it take to make a home? She asked in a sharp tone. 'If she was drowning in her own tears and choking on her own screams, would you still not want her to walk through the door of this house? (Ahmad, 2014:147).

These emotions beautifully express the intensity of pain which Nisa feels when she goes through the physical, sexual, psychological, and emotional and all other kinds of abuses at the hands of her husband in her most cherished and protected space of being i.e. her very own home. Welter (1966:162) enlists the attributes associated with feminine and masculine, women in this scenario are always expected to be weak, timid and dependent. Men on the other hand are supposed to be strong, wise and forceful. Teman and Miles (1936) attributed women as delicate, loving, caring and men quite the opposite. This work was made standard and used by Morawski (1985) and many others. These emotional responses also make women vulnerable to depression and anxiety women because of all the responsibilities they are loaded with by the society.

To what extent a woman should try to become what society wants her to be, and how much should she sacrifice for the sake of her home, her family when her family is ready to sacrifice none. The sacrifices made by Nisa were never acknowledged, she tolerated all the injustices, all the humiliations and forgave her husband every time, in hope for better future, hoping for change which never came. The concept of sisterhood, which is often associated with third world women, and inter racial 
differences of women is also applied in the context where women living in similar community face circumstances of oppression and violence and support each other. But in this context the gender roles assigned to women are so strong that they cannot unite against men to liberate themselves.

In the text, Nisa is aware of the fact that the role of her husband as breadwinner plays a vital role in her oppression and humiliation.

Towards the end of month when the money began to run out. A deep bitterness filled her. She had to turn to him again for more and had him spit on her face. These had always been the worst nights; his anger had sharper, more rigorous edge to it (Ahmad, 2014:154).

Nisa becomes aware of her role as a house wife, as a woman, as a wife and as a mother but in her heart she never acknowledges the way she is treated. She "resented him as deeply as he resented her demands" (Ahmad, 2014:154). it was not the house hold labors which humiliated her, house work alone was not the source of her oppression it was not the daily chores of cooking, cleaning ad nursing which made her miserable but "it was that physical humiliation, borne in silence five nights out of ten, which was consuming her" (Ahmad, 2014:152). This physical humiliation is not only a reference to his beatings, his physical violence but "overbearingly vicious assertion of his conjugal rights" (Ahmad, 2014:152). It was always against her will and she hated it, hated him deeply for this. She remained silent and performed it as part of her obligation, like other house hold chores. But from inside she felt resentful, she felt ashamed of herself and it was deeply disrespectful for her physical being to be humiliated like this every other night.

Regardless of social roles and gendered expectations one must define his/her own gender and define its attributes accordingly. Nisa does not submit to her husband's will and she refuses to be defined or labeled by the social norms though she secretly expects and hopes for her husband to change, to become a better person, "each time she saw the moon she prayed for the better month but things did not change-except within her heart, her attitude to her own body changed subtly" (Ahmad, 2014:154). Nisa grew into someone stronger, someone more powerful, not fearful to defy. She became empowered and it was all on her own, she was enlightened and she refused to be humiliated in the worst possible way every day. It was her first step towards understanding her own power she knew there is no magic in this world which can give her power. She had to empower herself through resistance. So, for a woman to empower herself, it takes double the strength and courage as a man since society never aids this empowerment.

The growth of Nisa's character and many other women we see around us into powerful beings is in itself rejection of ideas given by Foote (1956) and Bernard (1976) presented 
in the theory of outgrowth related to gender roles, where house wives being stuck in dead end profession are not able to grow and husbands out grow them. Here in this case, Nisa being a house wife out grows her husband who never tried to change or grow into someone better.

The knowledge that Talat had imparted on her of that strange sinful spell had given her a sense of strength. From a shivering, huddled creature Nisa had changed into a much calmer, more pensive woman (Ahmad, 2014:155).

The word "spell" and "sinful" here are very significant specially related to the title of story "the spell and the ever changing moon" each and every image here carry symbolism. Many symbols out of these carry significance related to gender roles and gendered identity of women. The spell given by Talat to Nisa is not a conventional magic, it's the secret of power, power every woman possess but never dream to achieve. It is referred as "sinful" as it is not permitted by society, nor encouraged. Women asking for their rights and resisting against male superiority is still considered to be associated with sin and evil. When an older woman in neighborhood sees Nisa with "the black eyes, the swollen lips or bruised face" which became more frequent after she denied her husband the right of physical humiliation (conjugal rights) she condoles to her by saying "oh! That man, beti. God will reward you for your patience" (Ahmad, 2014:155). This very comment tells us a lot about the society and social approval of domestic violence/abuse of women at the hands of the men who are supposed to be their protectors. Resistance is never encouraged, instead women are being praised for all the sacrifices and such women become the ideal face of feminity. The role models represent to the holy, gentle, caring, sacrificing, submissive and pious nature of women. As these are the traits required by the females whether from upper or lower class of society, Nisa is the face of every house wife, every woman who refuses to be great and instead become human only.

Different forms of female resistance to avoid violence/abuse include use of language, leaving the home, poisoning, physical violence, being armed, and being rebellious (Katrak, 2006). Different forms of resistance are adopted by Nisa in the story. After going through the long and painful journey of self-realization, When Hameed, her husband tries to hurt her physically, by using force her reaction is more shocking than anticipated by the reader.

She became hysterical. No. No. No. She was screaming. Don't touch me.

Don't come near me. I'll kill you. I'll stab you. I'll poison you. Words poured out of her as fast as the blood that sprang from her wound (Ahmad, 2014:157). 
This form of resistance is an indicator that she does not wish to tolerate the injustices of her husband anymore and does not care about the society either, their expectations and consequences. Moreover, after reading the story till its very end reader come to know that Nisa leaves her house, her husband and two of her children and goes to her mother's house. With her youngest child she leaves next day. She knows it will be very hard. She did not leave all her children and did not wanted to leave her house but she knew it will be impossible for her to live here after knowing that she can never change Hameed. He would always hurt her and disgust her. She did not want to earn she never wanted to work outside her house. But in crucial circumstances she was ready to face challenges. "If nothing else, I can wash dishes and cook. If Hameed won't keep Safia and Kareem let him dump them in Sialkot too" (Ahmad, 2014:158). Her strength and determination with a little hint of hope is evident in the concluding lines of the story:

As Nisa turned away and walked out of the courtyard, clothing both Zafar and the silver trunk, her steps were slow but firm and determined in her heart, Nisa wished she knew a spell that worked (Ahmad, 2014:158).

The strength of Nisa pass chills through his spine of readers and her determination gives hope. Reader feels extremely happy for her to get out of an abusive relationship which most of the women are never able to do. At the same time, one feels deep pain for her misfortunes, all her struggles, her rough circumstances and obstacles she is yet to face. The very last words of story are even more painful as the reader realizes that she never wanted to leave. She wants to stay. She wished she could have done anything differently, or there was some magic if there is any which could change her husband. Make him a better person which she was not able to accomplish in six long years of her companionship. Jalal-ul-Din and Khan (2008:489) state:

Under such situation, frequent training and awareness programs are needed to be arranged periodically to make women aware of their rights and equip them for exercising just demands. As has been suggested, various cottage industries by the public as well as private sectors should be established to provide job opportunities to rural women so that they can earn income and help their heads in household's expenses.

The character of Nisa, in the story, is symbolic for all the women who live in abusive relationships thinking that the conditions might change, their partners may change and transform in future. But eventually the realization should come that the only change they are looking for is yet to come from them. Domestic violence must be resisted, to preserve one's own self and for the betterment of coming generations. When Nisa has choice to become a saint, a holy woman who submits to the will of her husband as 
expected by the society or be a human who wants to live a happy life, where she can respect her own self, her physical being, her body and sexuality. She chooses to be a human. She chooses herself. It becomes a difficult decision, very difficult to act upon. But she knows she ultimately has no choice. She has to do it to live. She could not hope for her husband to change for another six years. She had waited enough. "Nisa decided she preferred the bruises to humiliating forced sex. She wasn't sure she wanted rewards in heaven; she only wished she had to suffer less on earth" (Ahmad, 2014:155). Nisa, thus stands for the experiences of women in general instead of singular experience and becomes the epitome of a woman who can be a mother, a daughter, a good wife and so much more without being a saint who has to sacrifice herself for the sake of her husband's will.

\section{Conclusions}

A Pakistani middleclass housewife needs more than just women empowerment; she wants to live happily, with her family her children where she can serve them joyously, work for them and care for them. In exchange she only needs some words of appreciation, a little respect from her husband and some confidence to believe in herself. Moreover, economic freedom can be a catalyst to women empowerment in our society. As Isran \& Isran (2012:853) pose that "as woman's economic dependence on men is seen as a consequence of patriarchal structure, women's economic participation is essential for removing their persistence subordinate position." A Pakistani housewife thus does not want to revolt, she is not a rebel, and she is a powerful woman who needs a little acknowledgement and small amount of love in exchange with all the hard work and physical labor she puts in for the betterment of her household. She doesn't want to get rid of her responsibilities, but she wants a little help from her spouse. A tiny bit of encouragement and she will be the most loyal, selfless being for her whole life. Who will not think of anything but betterment of her house, her children and her family.

\section{References}

Ahmad, R. (2014). The Gatekeeper's Wife: The Spell and the Ever Changing Moon. Lahore: ILQA.

Ali, T., Krantz, G., Gul, R., Asad, N., Johansson, E. \& Mogren, I. (2011). Gender Roles and their Influence on Life Prospects for Women in Urban Karachi, Pakistan: A Qualitative Study. Global Health Action, vol.4, p.7448. 
Bernard, J. (1976). The Wife's Marriage; The Future of Marriage, Harmondsworth: Penguin. pp.56-68.

Bhattacharya, S. (2014). Status of Women in Pakistan. J.R.S.P, vol.51:1, pp.179-211.

Butler, J. (1990). Gender Trouble: Feminism and the Subversion of Identity. New York and London: Routledge.

Chaudhry, I. S. (2005). Gender Inequality in Education and Economic Growth: Case Study of Pakistan. Paper presented at International Conference on Women in Nation Building at Bahaudin Zakariya University, Multan, Pakistan.

Chodorow, N. (1978). The Reproduction of Mothering: Psychoanalysis and the Sociology of Gender. Berkeley: University of California Press.

Delphy, C. (1984). Close to Home: A Materialist Analysis of Women's Oppression. Trans. Diana Leonard. Hutchinson: London.

Eagly, H. A., \& Steffen, J, V. (1984). Gender Stereotypes Stem From the Distribution of Women and Men Into Social Roles. Journal of Personality and Social Psychology, vol.46:4, pp.735-754.

Eccles, S. J., Jacobs, E. J. \& Harold, D.R. (1990). Gender Role Stereotypes, Expectancy Effects, and Parents' Socialization of Gender Differences. Journal of Social Issues, vol.46:2, pp.183-201.

Fikree F.F \& Pasha, O. (2004). Role of Gender in Health Disparity: In the South Asian Context. BMJ 2004, vol.328, pp.823-6.

Foote, N. (1956). Matching to Husband and Wife in Phases of Development: Transactions of the Third World Congress of Sociology, 4.

Freud, S. (1927). Some Psychological Consequences of the Anatomical Distinction between the Sexes. International Journal of Psychoanalysis, vol.8, pp.133-142.

Gilligan, C. (1982). In a Different Voice: Psychological Theory and Women's Development. Cambridge: Harvard University Press. 
Godey, X. (1839). Godey's Lady's Book. Hathi Trust, University of Michingan \& Minnesota: NewYork.

Guillaumin, C. (1996). The Practice of Power and Belief in Nature. Sex in Question: French Materialist Feminism. Ed. Diana Leonard and Lisa Adkins, London: Taylor and Francis.

Hussain, M., Naz, A., Khan, W., Daraz, U. \& Khan, Q. (2015). Gender Stereotyping in Family: An Institutionalized and Normative Mechanism in Pakhtun Society of Pakistan. SAGE Open.I-II.

Hussain, S., Habib, B. \& Akhter, J. (2014). Computational Analysis of Stereotypes as Cause of Gender Inequality: A Study of Universities of South Punjab, Pakistan. Pakistan Journal of Social Sciences, vol.34:2, pp.473-484.

Isran, S. \& Isran, A.M. (2012). Low Female Labor Participation in Pakistan: Causes and Consequences. Pakistan Journal of Social Sciences (PJSS), vol.32:2, pp.453-468.

Isran, S. \& Isran, A.M. (2012). Patriarchy and Women in Pakistan: A Critical Analysis. Interdisciplinary Journal of Contemporary Research in Business, vol.6, pp.835-859.

Jalal-ud-Din, M. \& Khan, M. (2008). Socio-economic and Cultural Constraints of Women in Pakistan with Special Reference to Mardan District, NWFP Province. Sarhad J. Agric., vol.24:3, pp.485-493.

Katrak, H, K. (2006). Politics of the Female Body: Postcolonial Women Writers of the Third World. Rutgers University Press.

Kohlberg, L. (1966). A Cognitive-Developmental Analysis of Children's Sex-Role Concepts and Attitudes. In Eleanor E. Maccoby (Ed.), the Development of Sex Differences. Stanford: Stanford University Press.

Kruger, R.L.M. (1997). The Influence of Gender Stereotypes and Roles on Managerial Performance of Women Education Leaders (Unpublished thesis). University of the Free State, Bloemfontein, South Africa.

Kuhlemann, A. (2016). Detecting a Feminist Reading Model: Clues in Marcela Serrano's Nuestra Señora de la Soledad and in Responses from her Women Readers. Reception: Texts, $\quad$ Readers, Audiences, History, vol.8:1, pp.45-72. 
Kusch, C. (2016). Literary Analysis: the Basics. Routledge.

Lorber, J. \& Farrell, S. A. (1991). The Social Construction of Gender. Park,Calif: Sage Publications.

Morawski, J. G. (1985). The Measurement of Masculinity and Femininity: Engendering Categorical Realities. pp. 108-135 in Abigail J. Stewart and M. Brinton Lykes (Eds.), Gender and Personality: Current Perspectives on Theory and Research. Durham: Duke University Press.

Nashua, N.H. (1849). The Bachelors Dream in the Ladies Gift: Souvenir of all Seasons, pp.37.

Riesman, D. (1964). Introduction to Jessie Bernard: Academic Women, The Pennsylvania state university press, Philadelphia, part xxiv.

Ruthven, K, K. (1984). Feminist Literary Studies: An Introduction. Cambridge University Press.

Saeed, A. \& Khan, A. (2017). The Role of Ideological State Apparatuses in Identity Formation in Qaisra Shahraz's The Holy Woman. Pakistan Journal of Gender Studies, vol.14, pp.37-52.

Salter, P. (1970). What Hath Spock Wrought? Washington Post, part 1.

Spence, J.T. \& Robert L.H. (1978). Masculinity and Femininity: Their Psychological Dimensions, Correlates, and Antecedents. Austin: University of Texas Press.

Spence, J. T. \& Helmreich, R. (1980). Masculine Instrumentality and Feminine Expressiveness: Their Relationships with Sex Role Attitudes and Behaviors. Psychology of Women Quarterly, 5, pp.147-163.

Stets, J. E. \& Burkes, J.P. (1996). Gender, Control, and Interaction. Social Psychology Quarterly, 59, pp.193-220.

Terman, L. M. \& Miles, C. (1936). Sex and Personality. New York: McGraw-Hill.

Waring, M. (1998). If Women Counted: A New Feminist Economics. Harper San Fransico. 
Welter, B. (1966). The Cult of True Woman hood 1820-1860. American Quarterly, Volume, vol.18:2, part 1, pp.151-174.

Weitzman, L. J. (1979). Sex Role Socialization. Palo Alto, CA: Mayfield.

Worell. J. (2002). Encyclopedia of Women and Gender: Sex Similarities and Differences and the Impact of Society on Hander, Academic Press, University of Kentucky, Lexington.

Dr. Amna Saeed is an Assistant Professor in the Department of Humanities, COMSATS Institute of Information Technology, Islamabad.

Noreen Zainab is Research Scholar in the Department of Humanities, COMSATS Institute of Information Technology, Islamabad. 